УДК 94 (477) : 351.74 «1943/1946»

DOI: 10.26693/ahpsxxi2020.02.021

\title{
ФОРМУВАННЯ ТА ДІЯЛЬНІСТЬ «СМЕРШ» У 1943-1946 рр.
}

\author{
Ірина Міронова, \\ e-mail: ya.Irina761@gmail.com \\ ORCID: https://orcid.org/oooo-ooo2-3039-742X \\ Чорноморсъкий національний університет імені Петра Могили, \\ Україна, 54оо3, м. Миколаїв, вул. 68 Десантників, 10 \\ Людмила Черничко, \\ e-mail: cernickoludmila88@gmail.com \\ ORCID: https://orcid.org/oooo-ooo1-7195-3093 \\ Чорноморсъкий національний університет імені Петра Могили, \\ Украӥна, 540о3, м. Миколаїв, вул. 68 Десантників, 10
}

У статті розглядаються організаційно-функціональний устрій органу радянсъкої спецслужби та підрозділу воєнної контррозвідки «СМЕРШ», на який покладався захист Діючої армї під час Другої світової війни. Подано фактологічнодокументальні джерельні підходи у дослідженні структури та діяльності розвідувальної організациї у зазначений період. Неупереджено й об'єктивно розглянуто оперативне мистецтво у залежності від зміни стратегічної ситуациї. До уваги представлено здатність організаційної структури та оперативні функцї̈ війсъкової контррозвідувальної служби, у контексті й̈ діяльності, вести боротьбу зі спецслужбами противника як в авангарді, так і в тилу армї̈. Зроблено аналіз війсъкової контррозвідки «СМЕРШ» у контексті війсъково-стратегічної ситуацій та як наслідок перетворення радянсъких спецслужб.

Ключові слова: Друга світова війна, спецслужби, контррозвідка, радіоконтррозвідка, розвідка, агентурна робота, оперативне мистецтво, вербування

Постановка проблеми. До початку радянського періоду, Україна хоч і зберігала певною мірою автономію, однак постійно мала оборонятися від загарбників, насильницьких заходів щодо повної втрати державності та підпорядкуванню агресору, штучного зрощення з його культурою, законами та порядками. У такому широкому спектрі проблем не останнє місце займали розвідувальні органи, які ще у сукупності з відсутністю кваліфікованих кадрів і постійною зміною обстановки не мали можливості та не могли у повній мірі виконати покладені на них функції збирання, обробки та надання органам правління розвідувальної інформації, яка змогла б певним чином попередити про наміри чи діяння сусідніх держав. Аналіз наявних історичних матеріалів даного періоду, у порівняльному аспекті, дає можливість нам навчитися на помилках минулого для забезпечення власної безпеки та отримання переваг в області збройних сил, військових дій, політики та економіки.

Аналіз останніх досліджень. Аналіз історіографічної бази проблеми свідчить, що найпомітнішу групу наукових праць щодо розвитку форм й методів діяльності органів контррозвідки з захисту армійських лав створили фахівці центральних навчально-наукових установ радянської спецслужби, зокрема, О. Іванков ${ }^{1}$, В. Коровін ${ }^{2}$

\footnotetext{
${ }^{1}$ Иванков, А.В. (1985). Из опыта работы чекистов Украины в период борьбы с немецкофашистскими окупантами. Сборник Высших курсов КГБ СССР, 13, 14-23.

2 Коровин, В.В. (1980). Органы государственной безопасности в годы Великой Отечественной войны 1941-1945 г2. Москва: РИО ВКШ КГБ СССР.
} 
та ін. Серед сучасних історико-документальних праць варті згадки роботи К. Дягтерьова та О. Колпакіді 3 , О. Кокуріна та Н. Петрова4.

3-поміж наукових здобутків сучасних українських дослідників назвемо, передовсім, праці В. Бихова5 з історії військової контррозвідки в Україні. Автор дослідив розвиток оперативної обстановки напередодні нападу нацистської Німеччини та під час війни, зупинився на формуванні організаційних структур військової контррозвідки, розкрив основні функції, завдання, форми та методи діяльності військової контррозвідки в умовах стратегічної оборони та наступальних операцій. Становлення структур військової контррозвідки досліджували О. Божко ${ }^{6}$ та Ю. Терещенко7, історикоправовий аналіз радянських органів військової контррозвідки здійснив у своїх працях В. Окіпнюк 8 .

Метою статті $\epsilon$ з'ясування напрямів роботи контррозвідувальної організації «СМЕРШ» у роки Другої світової війни та перший повоєнний рік, переваг і недоліків розвідувальної роботи, розкриття впливу органів державної безпеки на функціонування радянської системи управління в цілому.

Виклад основного матеріалу. «СМЕРШ» (скорочення від «Смерть шпигунам!») є назвою трьох незалежних одна від одної контррозвідувальних організацій в СРСР у часи Другої світової війни та перший повоєнний рік. Постановою РНК СРСР № 415-138-сс від 19 квітня 1943 р. Управління особливих відділів НКВС СРСР було передане в Наркомат оборони СРСР, де на його основі утворене Головне управління контррозвідки Наркомату оборони «СМЕРШ» (начальник - В. Абакумов, у лютому 1943 р. Абакумову було присвоєно спеціальне звання «комісар держбезпеки 2-го рангу»), яке підпорядковувалося безпосередньо головнокомандуючому ЗС СРСР И. Сталіну.

Відділ Управління особливих відділів НКВС СРСР з обслуговування ВМФ був переданий до Наркомату ВМФ СРСР. На базі цього відділу утворене Управління контррозвідки «СМЕРШ» Наркомату ВМФ. Положення про нього та про його органи на місцях затверджене 31 травня 1943 р. постановою Державного комітету оборони СРСР № 3461сc/OB (начальник - П. Гладков), яке підпорядковане наркому ВМФ СРСР М. Кузнєцову.

У лавах НКВС було створено відділ контррозвідки «СМЕРШ», (начальник С. Юхимович), який підпорядкований наркому внутрішніх справ СРСР Л. Берії9.

Відповідно до постанови Ради Народних Комісарів СРСР від 19 квітня 1943 р. № 415-138-сс зі структури НКВС СРСР вилучалися Управління особливих відділів, на їній базі утворювалося Головне управління контррозвідки (ГУКР) Народного комісаріату оборони (НКО) «СМЕРШ». 21 квітня 1943 р. уряд затвердив Положення про ГУКР «СМЕРШ», яким, зокрема, встановлювалася вертикаль органів військової контррозвідки: управління «СМЕРШ» на фронтах, відділи - в арміях, корпусах, дивізіях, бригадах, гарнізонах, укріплених районах, установах НКО тощо ${ }^{10}$.

\footnotetext{
3 Дягтерев, К., Колпакиди, А. (2012). Непобедимый СМЕРШ и его «волкодавы». Москва: ЭКСМО; Яуза.

4 Кокурин, А., Петров, Н. (1997). НКВД - НКГБ - СМЕРШ: структура, функции, кадры. Статья четвертая (1944-1945). Свободная мысль, 8-9, 82-106.

5 Бихов, В.Л. (1999). Військова контррозвідка в діючій Радянській армї в Украйні періоду 19411945 років: автореферат дис.... канд. істор. наук: 21.00.04. Київ: НА СБУ.

6 Божко, О.І. (2001). Особливі відділи в системі органів державної безпеки 1918-1946 pp. 3 архівів ВУЧК - ГПУ - НКВД - КГБ, 2, 281-315.

7 Терещенко, Ю.В. (2017). Організація і діяльність підрозділів контррозвідки «СМЕРШ» НКВС УРСР у 1943-1945 рр. Південноукрайнсъкий правничий часопис, 2, 150-156.

${ }^{8}$ Окіпнюк, В.Т. (2018). Радянські органи військової контррозвідки в Україні у період Другої світової війни. Історико-правовий часопис, 1 (11), 24-30.

9 Шаповал, Ю.І., Васильєв, В.Ю. (н.д.). СМЕРШ. Енциклопедія істориї Украӥни. Retrieved from http://www.history.org.ua/?termin=Smersh

${ }^{10}$ Божко, O.I. (2001), 282-283.
} 
У цьому документі було визначено конкретні завдання органів «СМЕРШ», зокрема:

- боротьба зі шпигунською, диверсійною, терористичною та підривною діяльністю іноземних розвідок у частинах і з’єднаннях Червоної Армії (ЧА);

- виявлення «антирадянських елементів» у частинах та установах ЧА;

- боротьба зі зрадництвом і зрадою Вітчизні у частинах та установах Червоної армії (перехід на бік противника, укривання шпигунів, сприяння їх роботі);

- викриття дезертирства і самопошкодження;

- $\quad$ фільтрація й перевірка військовослужбовців та інших осіб, що перебували в полоні й оточенні.

Типова структура Управління «СМЕРШ» фронту від квітня 1943 р. (338 штатних одиниць) включала:

- 1-й відділ 3 агентурно-оперативної роботи по штабу та управлінським органам фронту;

- $\quad$ 2-й відділ із зафронтової роботи, боротьби з агентами-парашутистами противника, військовополоненими, фільтрація;

- $\quad$ 3-й відділ - керівництво роботою інших органів «СМЕРШ» на фронті, протидія розвідці противника, дезертирству;

- $\quad$ 4-й відділ - слідчий, а також відділ кадрів, оперативного обліку тощо ${ }^{11}$.

Радянським контррозвідникам протистояв надзвичайно сильний супротивник сукупність спеціальних служб нацистської Німеччини та її союзників. Ще з 1930-х рр. спецслужби стали одним із найважливіших елементів експансіоністської політичної лінії та доктрини «тотальної війни» Третього Рейху. В Україні окупанти розгорнули потужну мережу карально-репресивних органів спеціального призначення, яка включала: 1) військову розвідку - абвер (який мав підрозділи власне розвідки, або абвер-1, диверсійно-підривної справи - абвер-2, військової контррозвідки - абвер-3), 2) таємну поліцію (гестапо), 3) поліцію безпеки (СД), 4) польову жандармерію, 5) охоронну поліцію, 6) поліцію порядку тощо ${ }^{12}$. Окрім того, діяли спецслужби сателітів Німеччини - таємна поліція (Сигуранца) та Служба спеціальної інформації (військова розвідка) Румунії, угорські розвідка та контррозвідка, спецоргани фашистської Італії. В Україні дислокувалося до 26 спецорганів противника, на потреби таємної війни на Східному фронті працювало до 60 німецьких спеціальних навчальних закладів, щорічно випускаючи до 10 тис. розвідників, диверсантів і терористів.

Головними противниками «СМЕРШ» у його контррозвідувальній діяльності були: абвер (німецька служба розвідки і контррозвідки в 1919-1944), польова жандармерія і Головне управління імперської безпеки Німеччини, фінська та румунська військові розвідки ${ }^{13}$.

Кадри для ГУКР «СМЕРШ» почали прискорено готувати за 6-9 місяців 1-а та 2-а московські (разом на 800 курсантів), Ташкентська (200), Хабаровська (250) школи, а також 4-місячні курси у Новосибірську та Свердловську.

Служба оперативного складу ГУКР «СМЕРШ» була вкрай небезпечною - у середньому оперативник служив 3 місяці, після чого вибував по смерті або пораненню. Першим фронтовим контррозвідником, удостоєним звання Героя Радянського Союзу (посмертно) був старший лейтенант П.А. Жидков - оперуповноважений відділення контррозвідки «СМЕРШ» мотострілецького батальйону 71-ї механізованої бригади 9-го механізованого корпусу 3-ї гвардійської танкової армії.

Військові контррозвідники 1, 2 і 3-го Українських фронтів лише з травня 1943 по червень 1944 р. виявили та знешкодили 622 співробітників та агентів ворожих спец-

${ }^{11}$ Ibidem.

12 Коровин, В.В. (1985). Советская контрразведка в годы Великой Отечественной войны. Труды ВКШ КГБ СССР , 35, 43-45.

13 Васильев, В. (1980). Из опыта контрразведывательного обеспечения особо важных объектов промышленности в годы Великой Отечественной войны. Сборник КГБ СССР, 87, 93. 
служб, перевербували 52 агентів, які прямували до радянських тилів, і самі впровадили у середовищі противника 289 оперативних джерел14. Усього за період війни контррозвідники затримали в Україні 7849 агентів спецслужб противника, 3 яких 6951 - німецької, 791 - румунської, 20 - угорської розвідок. 3 них 2574 агенти противник залишив перед відступом, а 508 - закинув у радянський тил, 175 було завербовано ще до війни.

Контррозвідники територіальних органів НКВС-НКДБ разом 3 органами «СМЕРШ» виявляли агентів спецслужб противника, захоплювали їхні документи, ліквідовували склади зброї та диверсійної техніки, яку залишила «п'ята колона». Всього безпосередньо за період звільнення України контррозвідники викрили 4822 агенти німецьких, румунських та угорських спецорганів.

Роботі органів військової контррозвідки були властиві й численні недоліки та серйозні правові відхилення, породжені як екстремальними умовами воєнного часу (враховуючи масовий притік некваліфікованих оперативних працівників і слідчих), так і традиційним для сталінської епохи нехтуванням нормами законності та правами людини.

Про це, зокрема, свідчать результати перевірки стану роботи органів військової контррозвідки Народного комісаріату Військово-морського флоту та Чорноморського флоту, яку провели бригади Управління особливих відділів НКВС СРСР (наказ НКВС СРСР від 18 червня 1942 р. № 001271). Оперативній діяльності цих структур, визнавалося у документі, властиві «занехаяність і серйозні недоліки у постановці агентурної та слідчої роботи, в окремих випадках злочинно-халатне ставлення до справи». Застосовуються незаконні методи професійної діяльності, співробітники припускаються аморальних вчинків. Практикуються безпідставні арешти, незаконні методи ведення слідства, внаслідок застосування яких оперпрацівники «отримували вигадані свідчення» про належність громадян до «контрреволюційних організацій і груп». Про це все свідчать статистичні дані арештів і покарань по лінії діяльності «СМЕРШ» та інших розвідувальних організацій ${ }^{15}$.

Також окремо можна розглянути проблему фільтраційної роботи контррозвідки, адже у сучасних популярних працях нерідко стверджується про ледве не поголівне репресування тих, хто пройшов через полон. У ході війни (на 1 березня 1944 р.) 3 312,5 тис. військовослужбовців-полонених, які пройшли перевірку в контррозвідувальних підрозділах, було заарештовано за підсумками фільтрації лише 3,6\% (11283 осіб), 2,6\% направлено до штрафних підрозділів, натомість 71,4\% передано військкоматам для призову в армію, решту - до промисловості, шпиталів тощо ${ }^{16}$.

Слід підкреслити, що окрім припинення розвідувально-підривної діяльності спецслужб противника, органи «СМЕРШ» вдавалися до активних контррозвідувальних заходів, зокрема самі розгортали розвідку за лінією фронту. Лише контррозвідники 4-го Українського фронту в 1943-1944 рр. вивели в тил противника 100 агентів. Як наслідок, у червні 1943 - червні 1944 рр. був виявлений 81 агент спецслужб ворога, закинутий у наш тил або підготовлений для цього, також знайшли 67 кадрових співробітників спецслужб агресорів, 34 агенти контррозвідувальних органів противника, 138 активних колаборантів. Деякі з агентів «СМЕРШ» узяли дієву участь у диверсійній роботі, ініціювали створення партизанських загонів. Поряд з цим було виявлено суттєві недоліки зафронтової роботи по лінії «СМЕРШ»: відсутність належної координації роботи з органами контррозвідки НКДБ, недостатню підготовленість агентури до тривалого перебування в тилу, незадовільне використання баз партизанського руху17.

14 Иванков, А.В. (1985), 14-23.

15 Душин, Н. (1985). Советская военная контрразведка в годы Великой Отечественной войны. Сборник КГБ СССР, 106, 8-9.

${ }^{16}$ Кокурин, А., Петров, Н. (1997). 9, 96.

${ }_{17}$ Советские органы государственной безопасности в Великой Отечественной войне. Сборник документов и материалов (1985). V, 547-549. 
Висновки. Отже, контррозвідувальна робота була провідним за значенням напрямом оперативної діяльності радянських спецслужб. Ї̈̈ вага для завдання поразки агресорам, включаючи українську ділянку Східного фронту (де в 1943-1944 pp. провели серію масштабних наступальних операцій стратегічного та фронтового рівнів, успіх яких мав значення для перемоги у Другій світовій війні у цілому) передусім визначалася значущістю захисту діючої армії, військового тилу й партизанського руху від розвідувально-підривних і диверсійно-терористичних зазіхань спецслужб країнагресорів.

Діяльність «СМЕРШу» сприяла встановленню прокомуністичних режимів у країнах Центрально-Східної Європи. Розвідувальна робота цієї організації була спрямована на тих, хто був запідозрений у співпраці з нацистами, і на осіб, які з тих або інших причин цікавили Москву.

Наприкінці війни й у перший повоєнний рік «СМЕРШ» активно займався перевіркою колишніх радянських військовополонених і репатріантів у організованих із цією метою спеціальних фільтраційних таборах (було перевірено понад 4 млн. осіб). Після перевірки чимало людей було відправлено до таборів на найтяжчі роботи. Окрім військовополонених, на територіях країн Центрально-Східної Європи дана розвідувальна організація сприяла інтернуванню й ув'язненню в таборах понад 208 тис. осіб, «здатних носити зброю», і понад 60 тис. осіб, що входили до пронацистських структур. Після закінчення війни, 4 травня 1946 р., органи військової контррозвідки було знову повернено з підпорядкування військового відомства до системи органів державної безпеки (на той час - МДБ СРСР); центральний орган військової контррозвідки іменувався 3-м головним управлінням МДБ СРСР.

Доля агентів «СМЕРШу» була вкрай небезпечна. Проте, важливо пам'ятати про той подвиг, який здійснили розвідники та бійці «СМЕРШ» поряд з іншими радянськими військами, які брали участь у радянсько-німецькій війні. Адже крім свого основного завдання, вони були змушені безпосередньо брати участь у боях. У них було коротке життя за життя держави, це була їх ціна Перемоги - перемога на невидимому фронті.

\section{REFERENCES}

Bozhko, O.I. (2001). Osoblyvi viddily v systemi orhaniv derzhavnoi bezpeky 1918-1946 rr. [Special departments in the system of state security bodies in 1918-1946]. Z arkhiviv VUChK - HPU $N K V D-K H B, 2,281-315$ [in Ukrainian].

Bykhov, V.L. (1999). Viiskova kontrrozvidka $v$ diiuchii Radianskii armii v Ukraini periodu 19411945 rokiv [Military counterintelligence in the current Soviet army in Ukraine in the period 19411945], (Extended abstract of Candidate's thesis). Kyiv: NA SBU [in Ukrainian].

Diagterev, K., Kolpakidi, A. (2012). Nepobedimyi SMERSH i ego «volkodavy» [Invincible SMERSH and his «wolfhounds»]. Moskva: EKSMO; Yauza [in Russian].

Dushin, N. (1985). Sovetskaia voennaia kontrrazvedka v gody Velikoi Otechestvennoi voiny [Soviet military counterintelligence during the Great Patriotic War]. Sbornik KGB SSSR, 106, 7-16 [in Russian].

Ivankov, A.V. (1985). Iz opyta raboty chekistov Ukrainy v period borby s nemetsko-fashistskimi okupantami [From the experience of the Chekists of Ukraine during the period of the struggle against the German-fascist occupants]. Sbornik Vysshikh kursov KGB SSSR, 13, 14-23 [in Russian].

Kokurin, A., Petrov, N. (1997). NKVD - NKGB - SMERSH: struktura, funktsii, kadry. Statia chetvertaia. (1944-1945) [NKVD - NKGB - SMERSH: structure, functions, personnel. Article four (1944-1945)]. Svobodnaia mysl, 9, 82-106 [in Russian].

Korovin, V.V. (1980). Organy gosudarstvennoi bezopasnosti $v$ gody Velikoi Otechestvennoi voiny 1941-1945 gg. [State security bodies during the Great Patriotic War 1941-1945]. Moskva: RIO VKSH KGB SSSR [in Russian].

Korovin, V.V. (1985). Sovetskaia kontrrazvedka v gody Velikoi Otechestvennoi voiny [Soviet counterintelligence during the Great Patriotic War]. Trudy VKSH KGB SSSR, 35, 42-54 [in Russian].

Okipniuk, V.T. (2018). Radianski orhany viiskovoi kontrrozvidky v Ukraini u period Druhoi svitovoi viiny. [Soviet military counterintelligence bodies in Ukraine during the Second World War] Istoryko-pravovyi chasopys, 1 (11), 24-30 [in Ukrainian]. 
Shapoval, Yu.I., Vasilev, V.Yu. (n.d.) SMERSH. Entsyklopediia istorii Ukrainy. Retrieved from http://www.history.org.ua/?termin=Smersh [in Ukrainian].

Sovetskie organy gosudarstvennoi bezopasnosti $v$ Velikoi Otechestvennoi voine Sbornik dokumentov $i$ materialov (1985). [Soviet state security bodies in the Great Patriotic War. Collection of documents and materials], V, 547-549 [in Russian].

Tereshchenko, Yu.V. (2017). Orhanizatsiia i diialnist pidrozdiliv kontrrozvidky «SMERSh» NKVS URSR u 1943-1945 rr. [Organization and activity of counterintelligence units «SMERSH» of the NKVD of the USSR in 1943-1945]. Pivdennoukrainskyi pravnychyi chasopys, 2, 150-156 [in Ukrainian].

Vasilev, V. (1980). Iz opyta kontrrazvedyvatelnogo obespecheniia osobo vazhnykh obieektov promyshlennosti v gody Velikoi Otechestvennoi voiny [From the experience of counterintelligence support of especially important industrial facilities during the Great Patriotic War]. Sbornik KGB SSSR, 87, 92-98 [in Russian].

Zhmakin, M.S. (2011). Smersh vs Abver. Sekretnye operatsii i legendarnye razvedchiki [Smersh vs Abwehr. Covert operations and legendary scouts]. Moskva: Ripol Klassik [in Russian].

Iryna Mironova,

Petro Mohyla Black Sea National University, Mykolaiv, Ukraine ORCID: https://orcid.org/oooo-0oo2-3039-742X

\section{Liudmyla Chernychko, \\ Petro Mohyla Black Sea National University, Mykolaiv, Ukraine ORCID: https://orcid.org/oooo-OoO1-7195-3093}

\section{Formation and activity of SMERSH in 1943-1946}

The article examines the organizational and functional structure of the Soviet secret service and the «SMERSH» (short for «Death to Spies!») military counterintelligence unit, which was responsible for the protection of the Active Army during the Second World War. Until the beginning of the Soviet period, although Ukraine retained some autonomy, it had to constantly defend itself against invaders, violent measures to completely lose statehood and subjugate the aggressor, and artificially merge with its culture, laws and regulations. In such a wide range of problems, not the least was occupied by intelligence agencies, which, combined with the lack of qualified personnel and the constant change of circumstances, were not able and could not fully perform their functions of collecting, processing and providing intelligence to the authorities, would in some way warn of the intentions or actions of neighboring states. One of such intelligence agencies in the Soviet Union was SMERSH, which was subordinated directly to the Commander-in-Chief of the USSR Armed Forces, J. Stalin.

SMERSH's main opponents in its counterintelligence activities were the Abwehr (German intelligence and counterintelligence service in 1919-1944), the field gendarmerie and the German Imperial Security Directorate, and Finnish and Romanian military intelligence. Throughout its existence, SMERSH employees have found more than one spy. But despite significant advances in the fight against espionage, the work of military counterintelligence was characterized by numerous shortcomings and serious legal deviations caused by both extreme wartime conditions (given the massive influx of unskilled operatives and investigators) and the traditional Stalinist regime, norms of law and human rights.

At the end of the war and in the first post-war year, SMERSH was actively involved in the inspection of former Soviet prisoners of war and repatriates in special filtration camps organized for this purpose (more than 4 million people were inspected). After the inspection, many people were sent to the camps for the hardest work.

Keywords: World War II, special services, counterintelligence, radio counterintelligence, intelligence, intelligence work, operational art, recruitment 